\title{
Regional Differences in Mortality from Diseases of the Circulatory System in Finland in the 1930s
}

\author{
VEIJO NOTKOLA
}

Research Fellow in Demography

Department of Sociology

University of Helsinki

\section{Introduction}

It has been shown in several studies that there are marked regional differences in cardiovascular mortality in Finland. Death rates are much higher in the eastern parts than in the western parts of the country (see for example Valkonen \& Niemi 1978). The causes of these differences are unknown.

The first study in which the regional mortality differences by cause were systemically examined, was done by Kannisto (1947). Kannisto found that mortality was highest in eastern and northern Finland. High death rates in northern Finland were caused by infectious diseases, but excessive mortality in eastern Finland was mainly due to cerebral hemorrhage and heart disease.

The data analyzed by Kannisto covered the period 1936-1944. Mortality differences in earlier periods have not been analyzed, although cause-specific mortality statistics are available. The purpose of this report is to describe mortality differences between eastern and western Finland for diseases of the circulatory system during the years 1929-1932 and to discuss possible causes of these differences. Closer examination of earlier regional mortality differences may contribute to attempts to explain the current mortality differences.

\section{Methods and materials}

In mortality statistics diseases of the circulatory system (morbi organorum circulationis) were defined as a specific cause of death in the year 1926 (Official Statistics of Finland VI, 90, 6). However, the classification of deaths was not done by physicians. Ministers were responsible for the registration and classification of deaths until the year 1936 (Official Statistics of Finland VI, 90, 6).

The period 1929-1932 was chosen for this study because the end of 1930 is the first date after 1926 for which the age structure by province is available. A four-year 
period around this date was chosen in order to obtain enough deaths per province for statistical handling. The age structure of the resident population by province was taken from the Official Statistics of Finland VI, 76. Data is not used on all provinces in this report. The province of Turku and Pori was chosen to represent western Finland and the province of Kuopio to represent eastern Finland. The province of Kuopio included the present provinces of Kuopio and Pohjois-Karjala (North Karelia).

Mortality ratios from all causes, from diseases of the circulatory system and from causes other than diseases of the circulatory system were calculated for the provinces selected. Since data on deaths classified by age, cause of death and province are not available during that period, indirect standardization had to be used. The source of deaths by cause and province is Official Statistics of Finland VI, 66-79. The standard set of age-specific rates used were those calculated for Finland in 1930-1931 (Table 1).

The youngest age groups $(0-19)$ were excluded, because the diseases of the circulatory system are uncommon in these age groups. The percentage of deaths in the 0-19 age group was estimated using the mortality distribution of Finland in $1930-1931$ as a base. It is estimated that in both areas $3.6 \%$ of deaths were in the age groups under 20.

$\mathrm{T}$ a b l e 1. Death rates in standard population. Finland 1930-31.

\begin{tabular}{|c|c|c|c|c|c|}
\hline $\begin{array}{l}\text { Resident } \\
\text { population } \\
\text { by age }\end{array}$ & $\begin{array}{l}\text { All deaths } \\
(1930+31 / 2)\end{array}$ & $\begin{array}{l}\text { Death } \\
\text { rate } \\
\times\end{array}$ & $\begin{array}{l}\text { Number of } \\
\text { deaths from } \\
\text { diseases of the }\end{array}$ & $\begin{array}{l}\text { Death } \\
\text { rate } \\
\times\end{array}$ & $\begin{array}{c}\text { Death rate } \\
\text { for other } \\
\text { causes }\end{array}$ \\
\hline $\begin{array}{c}\text { December } 31, \\
1930\end{array}$ & & 10000 & $\begin{array}{c}\text { circulatory } \\
\text { system } \\
(1930+31 / 2)\end{array}$ & 10000 & $\stackrel{\times}{\times}$ \\
\hline 332502 & 2560.5 & 77 & 83.5 & 2 & 74 \\
\hline 283251 & 2103 & 74 & 107 & 3 & 78 \\
\hline 245697 & 1853 & 75 & 137 & 5 & 69 \\
\hline 210163 & 1676.5 & 79 & 171 & 8 & 71 \\
\hline 193697 & 1831 & 94 & 284 & 14 & 79 \\
\hline 174240 & 2001 & 114 & 394 & 22 & 92 \\
\hline 154647 & 2370.5 & 153 & 558 & 36 & 117 \\
\hline 135087 & 2847.5 & 210 & 797.5 & 59 & 151 \\
\hline 95699 & 2901 & 303 & 931 & 97 & 205 \\
\hline 85011 & 3847.5 & 452 & 1111.5 & 130 & 321 \\
\hline 59807 & 4013.5 & 671 & 871.5 & 145 & 525 \\
\hline 38991 & 4095 & 1050 & 615.5 & 157 & 1050.2 \\
\hline 18678 & 2873 & 1538 & 218.5 & 117 & 1319 \\
\hline 7271 & 1417 & 1948 & 67 & 92 & 1856 \\
\hline 1207 & 444.5 & 3691 & 5.5 & 45 & 3645 \\
\hline 2035948 & 36834.5 & 180 & 6352.5 & 31 & 149 \\
\hline
\end{tabular}




\section{Results}

The age-standardized mortality from all causes, as well as mortality from circulatory diseases and from other causes was higher in eastern than in western Finland in the period 1929-1932. The east-west mortality difference in diseases of the circulatory system was greater than the difference in total mortality.

The results indicate that mortality from cardiovascular diseases was higher in eastern Finland than in western Finland as early as the late 1920s.

There are also some other data which are in accordance with this result. In the period 1900-1925 mortality due to causes other than infectious diseases, accidents, poisoning, and violence was higher in the Ilomantsi municipality (eastern Finland) than in the Pöytyä municipality (western Finland), (Notkola 1981, unpublished results).

$\mathrm{T}$ a b l e 2. Age-standardized death rates by cause in 1929-1932 in the provinces of Kuopio and Turku and Pori (Finland 1930-1931=100). Ages $0-19$ excluded.

$\begin{array}{lcr}\text { All causes of deaths } & \begin{array}{c}\text { Kuopio } \\ \text { (Eastern Finland) }\end{array} & \begin{array}{c}\text { Turku and Pori } \\ \text { (Western Finland) }\end{array} \\ \text { Total registered deaths } & 4147 & 5544 \\ \text { Expected deaths } & 3659 & 5820 \\ \text { SMR } & 113 & 95 \\ \text { Diseases of the circulatory system } & & \\ \text { Total registered deaths } & 696 & 813 \\ \text { Expected deaths } & 638 & 1005 \\ \text { SMR } & 109 & 81 \\ \text { All causes other than diseases } & & \\ \text { of the circulatory system } & & 4731 \\ \text { Total registered deaths } & 3451 & 4815 \\ \text { Expected deaths } & 3021 & 98 \\ \text { SMR } & 114 & \end{array}$

\section{Discussion}

The basic problem in analyzing regional mortality differences at the beginning of this century is that the statistics on causes of death are unreliable. $14.1 \%$ of all deaths were classified as unknown diseases during the period 1927-1935 (Official Statistics of Finland VI, 90, 6). Table 1 also indicates that in older age groups, especially, the classification did not work very well. Mortality from diseases of the circulatory system declines after the ages $70-74$. This is probably due to the fact that in older age groups the class of unknown diseases was used more often. The 
only way to overcome the problems of unreliability of mortality statistics would be to use cause-specific model life tables. Kannisto (1947) in his study of the period only ten years later was using more reliable data and got very similar results to those of this study. This suggests that the use of more reliable statistics would probably not affect the results greatly.

The causes of regional mortality differences are not known. In the light of the results of Kannisto's study and this study, it seems that the differences have been stable for at least 50 years. This implies that the cause of the regional difference is probably some factor in which the east-west difference has also been stable over this time.

Among the factors which have been thought to explain Finnish regional differences, at least genetic factors and environmental factors - especially the mineral and trace element content of the soil - have been quite stable for decades (Nevanlinna 1972, Karppanen et al. 1978). However, the regional differences in genetic structure are not great (Nevanlinna 1972) and the importance of minerals and trace elements in relation to the east-west difference still deserves further attention (Pyörälä \& Valkonen 1981, 53).

There are also other quite consistent differences between the regions. Smoking is one factor which has to be taken into account because smoking seems to have been more common in eastern than in western Finland from the end of the 19th century (Rimpelä 1978). Persistently higher mortality in eastern Finland is also in accordance with the hypothesis that a low standard of living or poor living conditions in childhood increases the risk of cardiovascular diseases (Forsdahl 1977). The province of Kuopio has been one of the poorest counties in Finland from the end of the 19 th century. For example in the year 1901 the housing density was 3.3 persons per room in the province of Kuopio! This compares to 1.9 persons per room in the province of Turku and Pori (Gebhard 1910, 37). The relative difference did not change during the period 1900-1950.

Another relevant risk factor of cardiovascular diseases is the fat content of the diet. At the beginning of this century the standard of living was much lower in eastern Finland than in western Finland. It could be assumed that the fat content of the diet was lower in eastern Finland. On the other hand, farming was based much more on dairy cattle in eastern than in western Finland (Manninen 1922, 142). In the province of Kuopio there were 45 cows per 100 persons in the year 1916, but in the province of Turku and Pori there were 33 cows per 100 persons.

Sometimes diseases of the circulatory system are considered diseases of affluence (Marmot 1980). It is interesting to note that mortality from cardiovascular diseases has for at least half a century been highest in eastern Finland, which has been one of the poorest areas in the country.

It seems that regional cause-specific mortality differences at the beginning of this century warrant more detailed analysis. The data from all provinces should be used. Moreover the deficiencies in cause-specific data should be evaluated thoroughly. Historical information about living habits (for example dietary habits) in different areas could be used in testing hypotheses about the causes of these differences. 


\section{References}

Forsdahl, A. (1977). Are poor living conditions in childhood and adolescence an important risk factor for arteriosclerotic heart disease? British Journal of Preventive and Social Medicine 31: 91-95.

Gebhard, H. (1910). Asunto-olot. Tilattoman väestön alakomitea. Tilastollinen tutkimus yhteiskuntataloudellisista oloista Suomen maalaiskunnissa v. 1901. Helsinki.

Kannisto, V. (1947). Kuolemansyyt väestöllisinä tekijöinä Suomessa. Helsinki.

Karppanen, H. \& Pennanen, R. \& Passinen, L. (1978). Minerals, coronary heart disease and sudden death. Adv. Cardiol. 25: 9-24.

Manninen, J. (1922). Pohjoisen Karjalan vanhanaikainen talous. Suomen historiallinen seura. Tutkimuksia V. Helsinki.

Marmot, M. G. (1980). Affluence, urbanization and coronary heart disease. In: Disease and urbanization (ed. E. J. Glegg \& J. P. Garlick). London.

Nevanlinna, H. R. (1972). The Finnish population structure. A genetic and genealogical study. Hereditas 71: 195-236.

Pyörälä, K. \& Valkonen, T. (1981). The high ischaemic heart disease mortality in Finland - International comparisons, regional differences, trends and possible causes. In: Medical aspects of mortality statistics (ed. H. Boström \& N. Lyingstedt). Stockholm.

Rimpelä, M. (1978). Aikuisväestön tupakointitavat Suomessa 1950-1970-luvuilla. (Adult use of tobacco in Finland in the 1950's to 1970's). (In Finnish with English summary). Tampereen yliopiston kansanterveystieteen laitos. Kansanterveystieteen julkaisuja M 40. Tampere.

Valkonen, T. \& Niemi, M-L. (1980). The development of male mortality by county and cause of death in Finland 1961-75. Working Papers No. 12. University of Helsinki, Department of Sociology. Helsinki. 